\title{
RADIOLABELED AOT FOR STUDIES OF THE PARTITIONING OF THE SURFACTANT DURING PROTEIN EXTRACTION BY MEANS OF REVERSE MICELLAR TWO-PHASE SYSTEMS
}

\author{
M. HENTSCH,* E. FLASCHEL,** A. RENKEN*+ \\ *Institute of Chemical Engineering, Swiss Federal Institute of Technology, EPFL, \\ CH.105 Lausanne (Switzerland) \\ **University of Bielefeld, Department of Technology, P.O. Bax 1001 31, D-33501 Bielefeld (Germany)
}

(Received December 7, 1994)

\begin{abstract}
Knowledge about the distribution of surfactants between aqueous and reverse micellar phases as well as the association of surfactants with proteins are of major importance for assessing the practical feasibility of protein extraction by means of reverse micellar systems. The question of the fate of the surfactant has been addressed for the classical reverse micellar system based on brine/AOT/isooctane. For this purpose, AOT (Aerosol OT, di-2-ethyl-1-hexyl sulfosuccinate) was synthesized in the presence of sulfite radioactively labeled with the isotope ${ }^{35} \mathrm{~S}$. The synthesis of $\left[{ }^{35} \mathrm{SIAOT}\right.$ as well as its use for tracer analysis in protein extraction are discussed.
\end{abstract}

Since the discovery that proteins may be transferred from aqueous into organic phase in the presence of adequate surfactants, ${ }^{1}$ the technique of protein extraction by means of reverse micellar systems or microemulsions has found considerable interest. Although many fundamental questions have already been addressed and feasibility studies have been carried out, there are still some major questions to be answered before this technique may become more generally accepted. One of these questions refers to the fate of the surfactant. Adequate surfactants capable of transforming liquid two-phase systems into so called Winsor-II systems are soluble in non-polar organic solvents as well as in aqueous solutions to various extents. This may lead to extensive losses of surfactants due to discarding the aqueous phase, particularly in continuous extraction processes. ${ }^{2}$ This question also relates to the precipitation of proteins by surfactants in the aqueous phase. ${ }^{3}$ In addition, for high purity proteins or proteins of pharmaceutical use contaminated with surfactants may be a crucial issue.

It has to be mentioned that the reverse micellar protein extraction involves two extraction steps. During the first step - called forward extraction - proteins are extracted from an aqueous phase into a reverse micellar phase. During the second step - called

${ }^{+}$To whom correspondance should be addressed. 
backward extraction - the proteins are re-extracted from the reverse micellar phase into a second aqueous (stripping) phase at altered $\mathrm{pH}$ or higher salinity.

A few reverse micellar systems have been studied only with respect to protein extraction. The system investigated most carefully consists of the surfactant AOT (Aerosol OT, sodium di-2-ethyl-1-hexyl sulfosuccinate), and isooctane in the presence of an aqueous salt solution. Although this system represents the standard reverse micellar system, not much is known about the distribution of AOT between the aqueous and the reverse micellar phase during protein extraction PRADKAR and DORDICK ${ }^{4}$ have studied the fraction of AOT remaining in the organic phase as a function of the concentration of the protein $\alpha$-chymotrypsin and of calcium chloride at a constant low global AOT concentration. A much broader analysis of the fate of AOT has recently been reported by ADACHI and HARRADA. ${ }^{2}$ These authors have studied the distribution of AOT during the extraction of cytochrome $c$ from brine into an AOT $/ n$-heptane reverse micellar phase. Data have been reported on the precipitation of cytochrome $c$ in the presence of AOT as well as on the influence of the $\mathrm{NaCl}$ concentration on the distribution of AOT in the range of AOT concentrations of $10^{-5}-2 \cdot 10^{-2} \mathrm{M}$ in the reverse micellar phase.

The main problem for following the distribution of surfactants during reverse micellar protein extraction is of analytical nature. Some analytical methods may be used for the quantitative determination of surfactants. ${ }^{5}$ Ionic surfactants like AOT may be analyzed by means of ion-pair extraction in the presence of a dye as the counter ion. Some methods based on ion-pair extraction are known ${ }_{r}{ }^{5}$ however, there is always the problem to be solved whether these methods may be applied in the presence of organic solvents, high sát wrentrations and proteins. The authors cited above have used colorimetric methods based on ion-pair extraction developed by ORTHGIESS and DOBIÁS ${ }^{6}$ and TAGUCHI and GOTO. ${ }^{7}$

Authors of the present paper confronted with the question, how to analyze AOT in aqueous and reverse micellar phases of varying composition decided to use a radioactive tracer technique, because methods based on radioactive decay are very sensitive and less affected by varying composition of the samples. A synthesis of AOT labeled with the isotope ${ }^{35} \mathrm{~S}$ has been worked out leading to reproduceable high yield and purity. The isotope ${ }_{16}^{35} \mathrm{~S}$ decomposes into ${ }_{17}^{35} \mathrm{Cl}$ by $\beta$-decay with a half-life of $88 \mathrm{~d}$. The energy of the $\beta$-particles liberated is characterized by a maximum at $49 \mathrm{keV}$ and a limiting energy of $167.4 \mathrm{keV}$. The AOT synthesis based on the procedure of JÄGER ${ }^{8}$ will be discussed together with the use of radiolabeled AOT for the determination of the AOT distribution in the two-phase system during reverse micellar protein extraction. 


\section{Experimental}

Materials and methods: For the synthesis of AOT, maleic anhydride (63 200) was purchased from Fluka as were 2-ethyl-1-hexanol (04 050), p-toluenesulfonic acid (89 760) and sodium hydrogen sulfite (71 670). Radioactively labeled sodium hydrogen sulfite $\left(\mathrm{NaH}^{35} \mathrm{SO}_{3}\right.$, SJ 99) was obtained from Amersham International in sealed ampoules with $0.2 \mathrm{ml}$ of a $0.5-1 \mathrm{M}$ aqueous solution with a specific activity for the ${ }^{35} \mathrm{~S}-\beta^{-}$-decay of $3.7-16 \cdot 10^{8} \mathrm{~Bq} \cdot \mathrm{ml}^{-1}$. For chromatographic separation silica gel (Kieselgel G60, 7734) of Merck was used. For scintillation counting the scintillation solution Ultima Gold ( 6013 329) of Packard Canberra was applied. Reverse micellar extraction systems were prepared with isooctane of UV quality (A 9901) from Romil Chemicals as well as AOT (D-0885) and lysozyme of egg white (L-6876) from Sigma. All other reagents were at least of analytical grade.

Radioactivity measurements were carried out on a Tricarb-Packard $2200 \mathrm{CA}$ Scintillation counter. Samples of $200-300 \mathrm{mg}$ were solubilized in $10 \mathrm{ml}$ of scintillation solution in polyethylene flasks. Activity data refer to mean values of triple measurements. The activity data were calibrated with respect to each initial AOT solution in isooctane.

The aqueous solution of the two-phase system of the forward extraction experiment contained $0.2 \mathrm{M} \mathrm{NaCl}$ in the presence of a $0.1 \mathrm{M}$ sodium phosphate buffer of $\mathrm{pH} 7$ and, eventually, $15 \mu \mathrm{M}$ lysozyme. The reverse micellar phase was prepared by solubilizing an adequate amount of AOT in isooctane. Equal volumes $(10 \mathrm{ml})$ of both phases were mixed in a stoppered glass flask of $60 \mathrm{ml}$ and agitated for 2 hours at $25^{\circ} \mathrm{C}$ on an orbital shaker type 3017 of GFL prior to taking samples.

The aqueous stripping solution for the backward extraction experiment contained $1 \mathrm{M} \mathrm{KCl}$ in the presence of a $0.05 \mathrm{M}$ Tris- $\mathrm{HCl}$ buffer of $\mathrm{pH} 8.2$. A volume of $10 \mathrm{ml}$ of the reverse micellar phase of a forward extraction experiment was mixed with an equal volume of stripping aqueous solution in a stoppered glass flask of $60 \mathrm{ml}$ and placed on the orbital shaker for 16 hours prior to taking samples.

The concentration of lysozyme was analysed by spectrophotometry at a wavelength of $278 \mathrm{~nm}$. A molar absorbance of $33.4 \mathrm{mM}^{-1} \cdot \mathrm{cm}^{-1}$ was applied for analysing aqueous phases and $35.6 \mathrm{mM}^{-1} \cdot \mathrm{cm}^{-1}$ in the case of reverse micellar phases.

Synthesis and purification of radiolabeled AOT: AOT was synthesized essentially according to the patent of Jaeger describing the synthesis of sulfonated dicarboxylic acids. ${ }^{8}$ The general strategy is outlined in Fig. 1. First, 0.31 mol maleic anthydride was esterified with $0.6 \mathrm{~mol}$ 2-ethyl-1-hexanol in $0.84 \mathrm{ml}$ toluene in the presence of traces of p-toluenesulfonic acid ( $p$-TSA) by means of azeotropic water removal at about the boiling point of toluene of $110^{\circ} \mathrm{C}$ in order to obtain di-2-ethyl-1-hexyl maleate. Maleic acid and the monoester were eliminated by extraction into a $1 \mathrm{M} \mathrm{NaOH}$ solution. The 


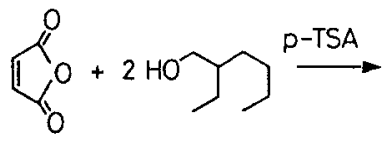

(1)

(2)

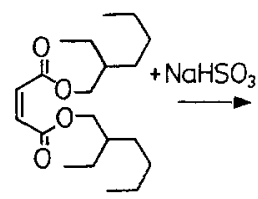

(3)

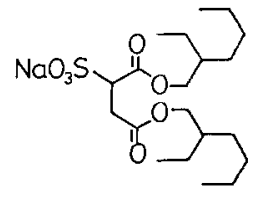

(4)

Fig. 1. Schematic presentation of the strategy of synthesis of AOT (4) from maleic anhydride (1), 2-ethyl-1-hexanol (2), and sodium sulfite via di-2-ethyl-1-hexyl maleate (3) according to the route of JAEGER ${ }^{8}$

Table 1

Typical composition of the reaction mixture for the synthesis of AOT from di-2-ethyl-1-hexyl maleate

\begin{tabular}{ccccc}
\hline Diester & $\mathrm{NaHSO}_{3}$ & $\mathrm{NaH}^{35} \mathrm{SO}_{3}$ & Methanol & Total volume, \\
$\begin{array}{c}\text { Mass/volume, } \\
\mathrm{mmol} / \mathrm{ml}\end{array}$ & $\begin{array}{c}\text { Mass/volume,* } \\
\mathrm{mmol} / \mathrm{ml}\end{array}$ & $\begin{array}{c}\text { Mass/volume, } \\
\mathrm{mmol} / \mathrm{ml}\end{array}$ & $\begin{array}{c}\text { Volume, } \\
\mathrm{ml}\end{array}$ & $\begin{array}{c}\mathrm{ml} \\
5.8 / 1.8\end{array}$ \\
$\begin{array}{c}3.1 / 0.7 \\
5.8 / 1.8\end{array}$ & $3.1 / 0.7$ & $0.14 / 0.2$ & 1.5 & 4.2 \\
& $0.53 / 1.0$ & 0.77 & 4.35 \\
\hline
\end{tabular}

* Refers to aqueous solutions.

Table 2

Typical operating variables for the synthesis of AOT from di-2-ethyl-1-hexyl maleate and AOT yields

\begin{tabular}{ccccc}
\hline $\begin{array}{c}\text { Operating } \\
\text { time, } \\
\text { h }\end{array}$ & $\begin{array}{c}\text { Operating } \\
\text { temperature, } \\
{ }^{\circ} \mathrm{C}\end{array}$ & $\begin{array}{c}\text { Operating } \\
\text { pressure, } \\
\text { bar }\end{array}$ & $\begin{array}{c}\text { Global yield } \\
\text { of AOT, } \\
\%\end{array}$ & $\begin{array}{c}\text { Yield } \\
\text { of }\left[{ }^{35} \text { S]AOT, }\right. \\
\%\end{array}$ \\
\hline 13 & 105 & 12.3 & 91.5 & 99 \\
10 & 105 & 12.3 & 95.4 & 91.7 \\
\hline
\end{tabular}

organic phase was washed three times with a saturated $\mathrm{NaCl}$ solution prior to drying it over $\mathrm{MgSO}_{4}$ and removing toluene by distillation in a rotating evaporator at reduced pressure. The diester di-2-ethyl-1-hexyl maleate was recovered by vacuum distillation at $3.5 \cdot 10^{-2}$ mbar and $168{ }^{\circ} \mathrm{C}$ obtaining a product with a refractive index of 1.455 . The yield was about $80 \%$ with respect to the alcohol.

The second step of the synthesis of radiolabeled AOT consisted in sulfonation of di-2-ethyl-1-hexyl maleate. For this purpose, radioactive as well as normal sodium sulfite was mixed with the diester in an aqueous methanol solution in proportions given in Table 1. Methanol was used as solvent because of enhanced solubility of the 


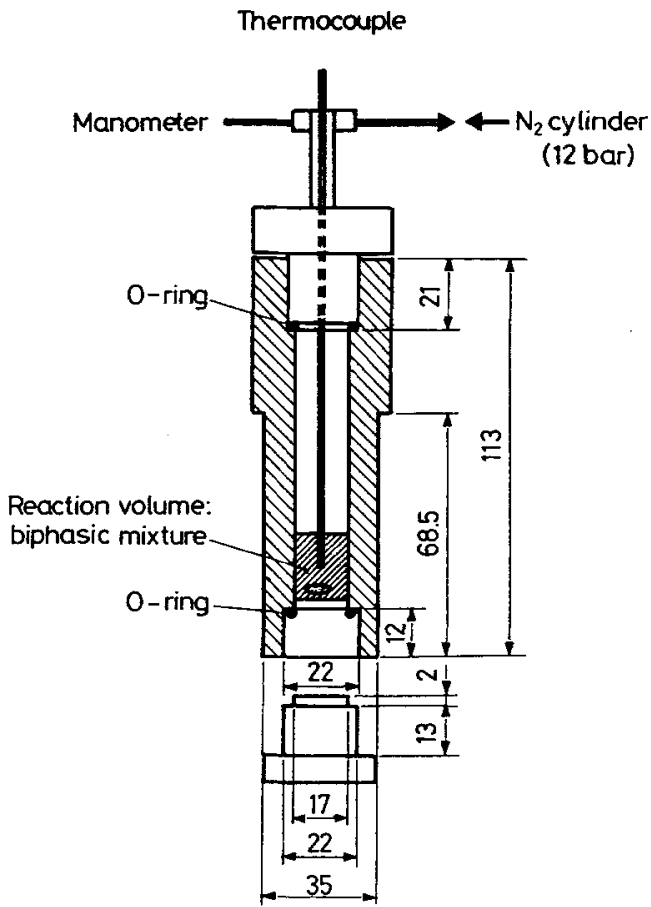

Fig. 2. Autoclave used for the synthesis of AOT from di-2-ethyl-1-hexyl maleate and radioactive sodium sulfite

reactants. The reaction was carried out in an autoclave shown in Fig. 2. The autoclave made of stainless steel has screw caps on both sides for better cleaning. It was filled with reactants under cooling with ice. The reactor volume was stirred by means of a magnetic drive. Pressurization was used in order to avoid decomposition of sulfite into sulfur dioxid, which could have lead to loss of valuable radioactive material. Therefore, once closed, the reactor was pressurized by means of a nitrogen supply of 12 bar prior to slowly heating to about $105^{\circ} \mathrm{C}$ in an oil bath. The autoclave was cooled down after having been kept for typically 10 hours at the reaction temperature. Typical reaction conditions and AOT yields with respect to either total sulfite or radioactive sulfite are summarized in Table 2.

The reaction mixture was evaporated to dryness and solubilized in $3 \mathrm{ml}$ ethyl acetate. This solution was applied to a chromatographic column of $5 \mathrm{~cm}$ in diameter filled with $60 \mathrm{~g}$ of silica gel, on top of which a layer of sand of $1 \mathrm{~cm}$ thickness should retain sulfite crystals. The column was developed with a solution of one volume of methanol in 10 volumes of ethyl acetate. An eluate volume of $130 \mathrm{ml}$ was sufficient to eliminate the 


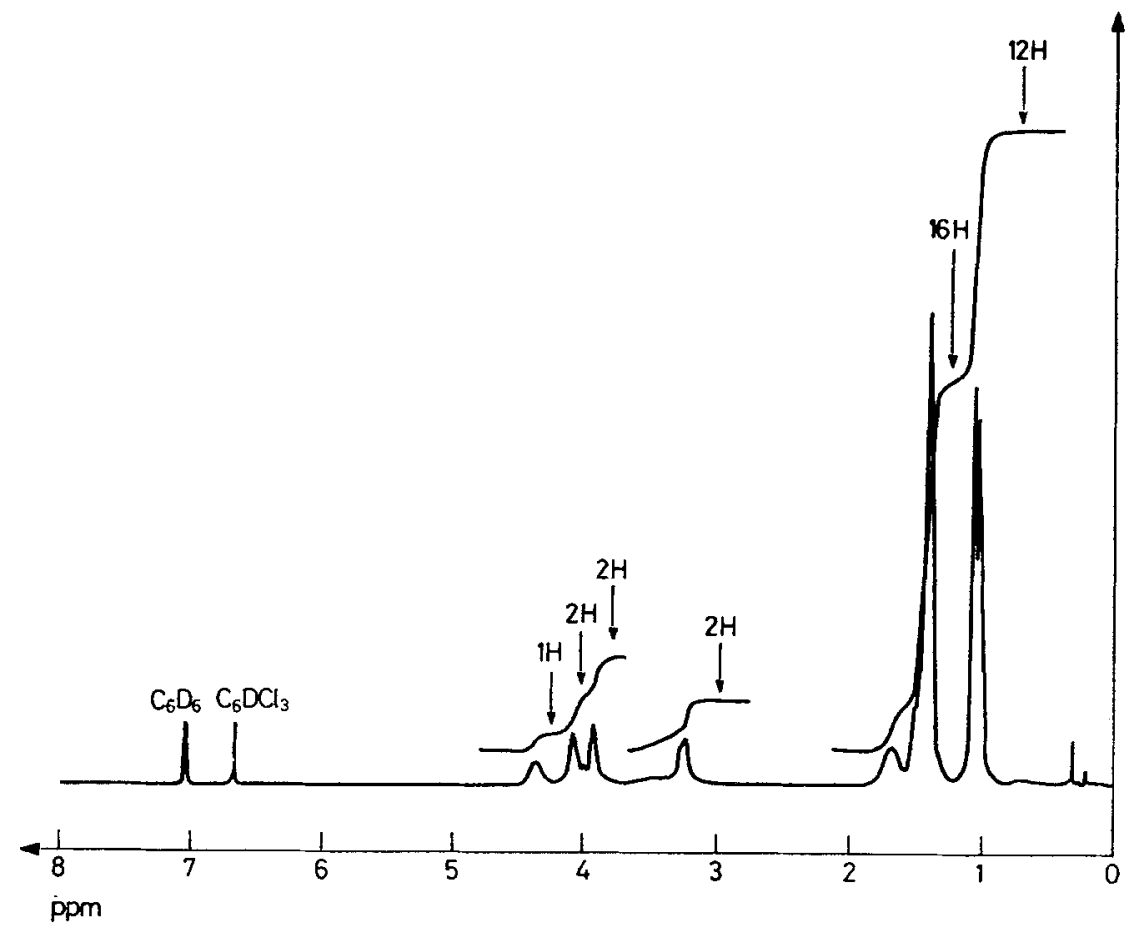

Fig. $3 .{ }^{1} \mathrm{H}-\mathrm{NMR}$ spectrum at $200 \mathrm{MHz}$ of $\mathrm{AOT}$ in $\mathrm{C}_{6} \mathrm{D}_{6}$ taken on a Bruker $200 \mathrm{AC}$ spectrometer; $\delta=4.25(1 \mathrm{H}), 4.1(\mathrm{~d}, 2 \mathrm{H}), 3.95(\mathrm{~d}, 2 \mathrm{H}), 3.1(2 \mathrm{H}), 1.6(\mathrm{~d}, 2 \mathrm{H}), 1.29(\mathrm{~s}, 16 \mathrm{H}), 0.89(\mathrm{~d}, 12 \mathrm{H})$

unreacted diester, whereas $300 \mathrm{ml}$ were necessary in order to recover AOT. The AOT fraction was evaporated to dryness and solubilized in $20 \mathrm{~g}$ isooctane for serving as stock solution, the specific activity of which (2nd example in Table 2) was analysed to be $1.51 \cdot 10^{4} \mathrm{~Bq} \cdot \mathrm{mg}^{-1}$ for an AOT concentration of $0.265 \mu \mathrm{mol} \cdot \mathrm{mg}^{-1}$. The yield of the second step was higher than $90 \%$ with respect to sulfite. The NMR spectrum of AOT synthesized by the procedure discussed is shown in Fig. 3. It may serve for documenting the purity of the surfactant obtained. Reverse micellar phases were prepared as to exhibit a specific activity of typically $150 \mathrm{~Bq} \cdot \mathrm{mg}^{-1}$ of isooctane solution.

Protein extraction: When an aqueous protein solution and a nonpolar organic solvent containing a reverse micelle forming surfactant are mixed, water, proteins and the surfactant will eventually find their equilibrium distribution between the aqueous and the reverse micellar phase. Since two extraction steps are required, surfactant may be lost during both forward and backward extraction in the aqueous phases. The initial aqueous protein solution would normally be discarded after extraction and the stripping aqueous phase would directly be transferred to a further protein purification process. 
Table 3

Partitioning of lysozyme and AOT in a reverse micellar two-phase system

\begin{tabular}{lcccc}
\hline \multirow{2}{*}{ Surfactant } & \multicolumn{2}{c}{ Initial concentration } & \multicolumn{2}{c}{ Final concentration } \\
\cline { 2 - 5 } & $\begin{array}{c}\text { Reverse } \\
\text { micellar phase }\end{array}$ & $\begin{array}{c}\text { Aqueous } \\
\text { phase }\end{array}$ & $\begin{array}{c}\text { Reverse } \\
\text { micellar phase }\end{array}$ & $\begin{array}{c}\text { Aqueous } \\
\text { phase }\end{array}$ \\
\hline $\begin{array}{l}\text { Forward extraction } \\
\text { Lysozyme, } \mu \mathrm{M}\end{array}$ & - & 15.6 & 15.8 & - \\
AOT, mM & 10 & - & 9.72 & 0.293 \\
Backward extraction & & - & - & \\
Lysozyme, $\mu \mathrm{M}$ & 15.9 & - & 9.68 & 0.0257 \\
AOT, mM & 9.7 & - & & \\
\hline
\end{tabular}

Therefore, the amount of surfactant partitioning into both aqueous phases would be lost for the process and would have to be supplemented in order to be able to re-use the reverse micellar phase for additional extraction cycles. In addition, the surfactant in the stripping aqueous phase may affect further purification steps.

A complete cycle of forward and backward extraction was performed for the extraction of lysozyme with an AOT-based reverse micellar solution according to the conditions given in Materials and Methods. The results in terms of protein and AOT concentrations are gathered in Table 3. Obviously, all the protein was taken up by the reverse micellar phase during the forward extraction. The AOT concentration in the reverse micellar phase dropped from 10 to $9.72 \mathrm{mM}$. In the aqueous solution, a corresponding AOT concentration of 0.29 was found. This implied that $2.9 \%$ of AOT was lost in the first extraction step. During backward extraction the additional loss of AOT was only about $0.26 \%$. This loss was rather low in comparison with the loss of the first extraction step owing to the much higher salt concentration in the stripping aqueous phase. Under the actual operating conditions a loss of AOT in the range of $3.2 \%$ had to be anticipated for a complete two-step extraction cycle.

In general, the presence of salt has a quite pronounced influence on the partitioning of AOT. ${ }^{3}$ However, the loss of AOT in the present system used is significantly higher than those reported for the system based on $n$-heptane as the nonpolar solvent under similar conditions. ${ }^{3}$ Different salts may have a quite different influence on the distribution of AOT in Winsor-II systems. ${ }^{3,4}$ This behavior may perhaps explain in part the influence of different salts on protein extraction. ${ }^{9-13}$ 


\section{Conclusions}

It has been shown that radioactive AOT may be prepared by means of a facile synthesis procedure introducing the isotope ${ }^{35} \mathrm{~S}$ into the sulfonate group of AOT. A simple chromatography on silica gel was sufficient for obtaining AOT in high purity. The $\beta$-decay of ${ }^{35} \mathrm{~S}$-AOT has advantageously been used for analysing the AOT concentration in both phases, the aqueous and the reverse micellar phase, during the extraction of lysozyme. The data showed that significant losses of AOT in the range of $3.2 \%$ would have to be anticipated under standard extraction conditions. Since most of the AOT was lost during forward extraction, this step will have to be re-examined. A following report will discuss the partitioning of AOT in reverse micellar two-phase systems more in detail. ${ }^{14}$

Financial support of the Council of the Swiss Federal Institutes of Technology is greatfully acknowledged. Handling of radioactive materials as well as radioactivity measurements were made possible by technical assistance of C. WASTIEL and the kind collaboration and advice of C. FRIEDLI and J. J. GOSTELY.

\section{References}

1. P. L. LUISI, F. J. BONNER, A. PELLEGRINI, P. WIGET, R. WOLF, Helv. Chim. Acta, 62 (1979) 740.

2. M. DECKER, K. VANT RIET, S. R. WEIJERS, J. W. A. BALTUSSEN, C. LAANE, B. H. BIJSTERBOSCH, Chem. Eng. J., 33 (1986) B27.

3. M. ADACHI, M. HARADA, J. Phys. Chem., 97 (1993) 3631.

4. V. M. PARADKAR, J. S. DORDICK, Biotechnol. Bioeng, 43 (1994) 529.

5. H. KÖNIG, Neuere Methoden zur Analyse von Tensiden, Springer-Verlag, Berlin, 1971.

6. E. ORTHGIESS, B. DOBIAS, Tenside Surf. Det. 27 (1990) 226.

7. S. TAGUCHI, K. GOTO, Talanta, 27 (1980) 289.

8. O. JAEGER, US Patent 2.028.091, 1933.

9. T. NISHIKI, I. SATO, T. KATAOKA, D. KATO, Biotechnol. Bioeng., 42 (1993) 596.

10. P. BRUNO, M. CASELLI, P. L. LUISI, M. MAESTRO, A. TRAINI, J. Phys. Chem., 94 (1990) 5908.

11. G. MARCOZZI, N. CORREA, P. L. LUISI, M. CASELLI, Biotechnol. Bioeng., 38 (1991) 1239.

12. B. A. ANDREWS, D. L. PYLE, J. A. ASENJO, Biotechnol. Bioeng., 43 (1994) 1052.

13. B. A. ANDREWS, K. HAYWOOD, J. Chromatogr. A, 668 (1994) 55.

14. M. HENTSCH, P. WARNERY, A. RENKEN, E. FLASCHEL, to be published. 